Tülay ZIVALI TURHAN

Hatice AYATAÇ

\title{
Understanding of the relation between ethnic diversity and public space: A bibliometric analysis
}

In its most obvious form, the mechanism of the "public" - the individuals in a society and their engagement with each other - can be seen in the core of the cities; the public space. Over the years, many scholars from various disciplines have contributed extensive research on this notion. This article provides a constructive analysis of research approaches and methodologies applied to ethnic diversity as a social phenomenon in relation to public space. It examines 1,079 articles published between 1995 and 2020 and included in Web of Science. The bibliometric dataset was manually filtered, and query-based scientometric visualization was produced using CiteSpace software. The article explores how theory is applied, and it outlines current trends, gaps, and common methodological approaches in the literature, which may lead to new insights for further interdisciplinary research. The results show two fundamental clusters in the theoretical conceptualization regarding the subject: a human-place relational approach, which is based on examining urban and social policy, and a human-human relational approach, which focuses on interpersonal interactions and considers public space a facilitator for this social encounter.

Keywords: bibliometric review, CiteSpace, ethnic diversity, public space, Web of Science 


\section{Introduction}

One prominent effect of the globalizing world is increasing migration and thus increasing diversity in urban settlements. Many large cities face a persistently high influx of immigrants from around the world. Consequently, populations are shifting toward a dynamic, heterogeneous, and multicultural structure with the presence of various ethnic groups and subcultures. Ethnic diversity can be observed from the (sub)national level to the neighbourhood level in both social and spatial organization. Ethnicity identifies shared attributes of groups of people and identifies common traditions, ideologies, and behaviours that show cultural continuity over time (Hutchinson \& Smith, 1996; Peoples \& Bailey, 2011). Eventually, people tend to congregate with others that have the same norms and values, and certain groups evolve with distinctive characteristics. Nevertheless, diverse individuals and groups of people are obliged to engage and share space with each other more than ever. This phenomenon has always been an issue in a wide range of fields such as geography, urban studies, sociology, environmental psychology, and cultural studies. The urban fabric plays a substantial and decisive role in shaping the relations between ethnic groups. Interaction between diverse ethnic communities in daily life occurs in commonly used spaces in the city; public space is the meeting place of different identities - or, as Sennett (2003) argues, the place where "strangers" meet each other. Common space is an always-fragile spatial situation that people shape through engagement. In addition, a person's cultural identification creates a sense of belonging and thus promotes meaningful places. Experiencing common spaces as they are is possible through their emergence in the process of being used, defined, comprehended, and communicated collectively (Stavrides, 2016). "Mainstream urban design theory and practice are explicitly pro-social; the importance of socialising in outdoor public spaces is promoted" (Rishbeth et al., 2018: 37) through various residential scales in the city (Jacobs, 1961; Whyte, 1980; Gehl \& Gemzoe, 1996; Carmona et al., 2003). In this manner, urban public space is the place where everyday practices reflect individual and collective social cultures of sociability (Dines et al., 2006) and is thus considered essential to the quality of life. According to Hillier (1996), the interface of ethnicity is one of the most critical among the multiple interfaces that characterize urban space. Hence, ethnic diversity appears as a social structure formed by the interaction of different communities in the urban landscape. Parallel to this urban sociological approach, the most integrated spaces in the spatial system attract more movement, and with their gravitational force they carry the potential for creating social interaction (Hillier et al., 1993). In this sense, it is essential to understand the role of ethnic diversity on public space, considering that these places are the most integrated spaces in the city. Ethnic groups tend to be spatially segregated from each other, but they are integrated into the system (proximate from any space of origin to all others in a system) as much as possible. However, the majority occupies the most integrated spaces, and the minority occupies secondary public spaces (Ferati, 2009). Although houses in diverse ethnic communities have the same spatial layout, it is their spatial configuration that discloses ethnic identity (Charambous Antoniadou \& Peristianis, 2001). In terms of sociability in public space, both disengagement and contact mechanisms occur as ethnic diversity increases (Blumer \& Solomos, 2015). Representations of the public space or representations of shared space (space as a common property of a group that symbolizes a common collective identity) are forms of creating the common space. As a matter of fact, common space may be contested in a struggle over representation even before it is defined as common space. These spaces are not merely the result of the acts that produced them or the acts of interpretation that name them. It is possible for common spaces to be misrecognized, corrupted, and even usurped within and through these struggles. It is important, then, to examine the ways in which people can develop tools to recognize, invent, and dream of common spaces (Stavrides, 2016).

To understand the trends of this dynamic and interdisciplinary concern, a common method is to conduct a literature review. It not only presents a multi-perspective overview of previous literature on the subject but also provides a foundation with possible objectives, methodologies, and indicators highlighting gaps and potentials regarding the topic (Khoo et al., 2010). It also provides a basis for larger studies related to the topic. By conducting a bibliometric analysis, Su et al. (2019) argue that the construction of a social model and its reflection in public space is based on the construction of the intangible cultural heritage of various ethnic groups. Shuangyun and Hongxia (2020: 27) state that "acculturation is not only a problem of immigrants but also a problem of ethnic minorities that have lived for generations in contact with mainstream groups." Andrade et al. (2016) review the dimensions of the "right to the city" and show that there has been an intensification of segregation in the last decade in urban public space. Overall, such studies point out that the impact of ethnicity and race cannot be underestimated in the formation of (in)tangible urban structures and relations, but signify that there are limited bibliometric studies addressing this issue.

Within this framework, this study examines the relation between ethnic diversity and public space based on a constructive analysis of the research approaches and methodologies used. The research identifies conceptual assumptions and the underlying trends in the past and present development of urban public space in relation to ethnic diversity. The article addresses 
Table 1: Inclusion and exclusion search criteria for the dataset.

\begin{tabular}{|c|c|c|c|}
\hline Criterion & Search terms & & \\
\hline Query entry & $\begin{array}{l}\text { ethnic* } \\
\text { racial* } \\
\text { racism }\end{array}$ & + & $\begin{array}{l}\text { public space* } \\
\text { shared space* } \\
\text { urban space* } \\
\text { urban public space* } \\
\text { open space* } \\
\text { open public space* } \\
\text { common space* }\end{array}$ \\
\hline Population & Ethnic groups & & \\
\hline Setting & Open public space accessible to all & & \\
\hline \multirow{2}{*}{ Outcome } & $\begin{array}{l}\text { Qualitative: perceptions and regulations regarding use of } \\
\text { public space by ethnic groups }\end{array}$ & & \\
\hline & $\begin{array}{l}\text { Quantitative: correlation between ethnic groups and use of } \\
\text { public space }\end{array}$ & & \\
\hline Publication type & Peer reviewed publications indexed in WoS databases & & \\
\hline Time span & $1995-2020$ & & \\
\hline
\end{tabular}

Note: The asterisk retrieves any group of characters, including no character, in Web of Science.

the dynamics and patterns of ethnic diversity in urban public spaces, arguing that the use of and engagement in the public sphere are affected by ethnic identity. In this way, it analyses the notion that ethnic diversity leads to socio-spatial segregation in public space.

\section{Research methods and tools}

\subsection{Search and selection process}

The research is based on publications from 1995 to 2020 taken from the Web of Science (WoS) bibliographic database. The support of bibliometric software (e.g., CiteSpace, HistCite, or VOSviewer) is very beneficial for tackling the complexity of such cross-domain research (Shuangyun \& Hongxia, 2020). Therefore, the data were analysed manually and with the help of CiteSpace software. This tool is used to translate bibliometric datasets into visualizations based on co-citations and clustering algorithms, and it makes it possible to explore the development of a certain research area (Chen \& Song, 2019). The search was conducted in July 2021 based on the title, abstract, publication information, keywords, and publication content. The following information was stored in the dataset during the search process: publication title, author information, publication source information, publication abstract, citation amount, and usage count. In addition, WoS provided specific information about individual publications, including the authors' keywords, WoS keywords (KeyWords Plus), author information, publisher information, document information, references cited, and other information related to the publication. The search query was "ethnic* OR racial" OR racism AND public space OR urban open space" and it

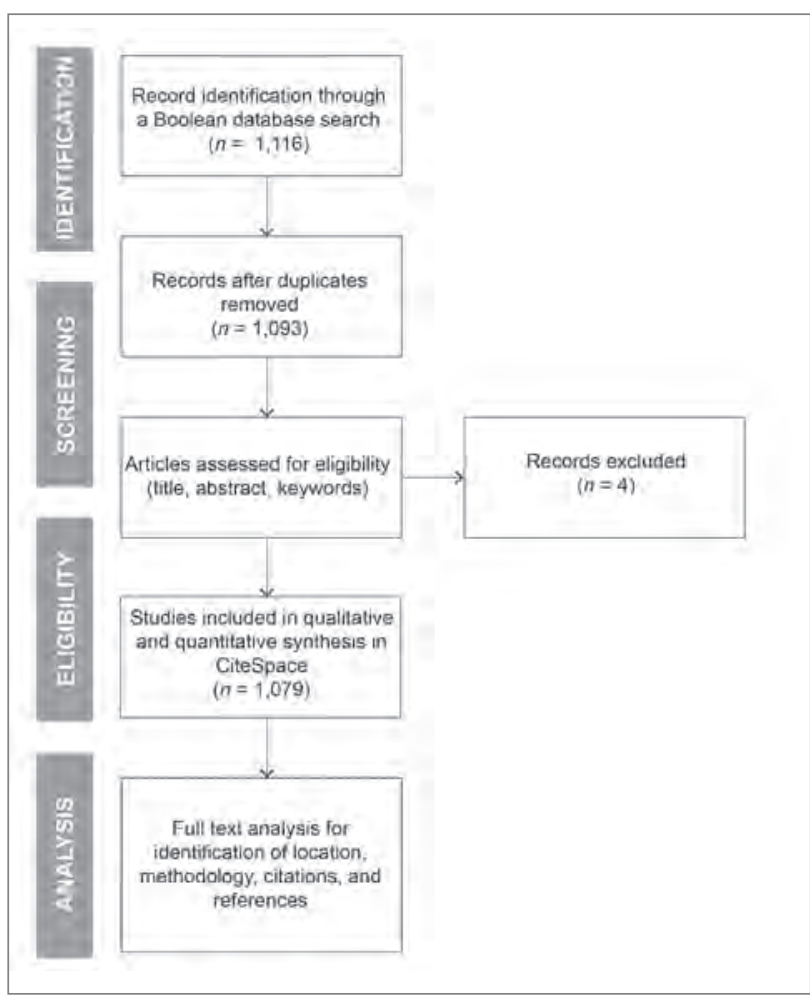

Figure 1: A PRISMA flow diagram showing the selection procedure and analysis of the dataset (illustration: authors).

included related terms that detected relevant residue regarding the subject and thus a more precise and substantial dataset (Table 1).

The set of terms and Boolean searches resulted in 1,116 hits (Figure 1). Then manual filtration was applied by reading the abstracts of the publications to attain greater accuracy and 
detect deviations and duplicates. The final dataset considered relevant for the study included 1,079 publications.

\subsection{Principal limitations}

"Interpretations based on the results of this methodology are limited by several factors. Firstly, WoS indexing practices can limit the reliability of the findings" (Le Gentil \& Mongruel, 2014: 87). The selected publications on this subject are not complete, and further material undoubtedly exists (e.g., in journals and books and/or book chapters not indexed in WoS, (un)published reports, dissertations, or (un)published conference proceedings). Second, the search output may have varied because different keywords related to the topic were included.

\section{Research findings on ethnic diversity in relation to public space}

The study comprehensively investigates the key thematic landscapes and their associated cluster patterns based on the bibliographic and geographic information, thematic areas, and methodological approaches of the data set.

\subsection{Bibliographic and geographic information}

The literature review retrieved a total of 1,116 publications from the WoS database, which were culled to 1,079 studies (96.7\%) dealing with ethnic diversity in public space. The document types are mainly research articles (93.4\%) and conference proceedings $(5.1 \%)$, which indicates that there is a certain degree of attention to the topic because some of the publications were presented at conferences. Although the search period covered almost a quarter century (1995-2020), half of the studies were published after 2015 (Figure 2). The overall citation counts of the selected publications clearly increased between 2013 and 2020, and they reached a peak in 2020. Although there are fluctuating intervals, an increase in such publications over time (more than $50 \%$ of all articles were published in the last decade) shows that there is increasing interest in and research on this subject. At the same time, the subject has gradually become integrated in various research areas. English is the predominant language of the publications, at $88.6 \%$. Among the non-English publications, Russian and Spanish (3.3\% and 3.2\%, respectively) were the most frequent.

Table 2 presents the WoS-assigned classification of the selected records into research areas. The majority of the publications are classified in the WoS category "Geography". The literature search resulted over 150 different journals. Despite this, there is no single academic journal devoted entirely to the relation between ethnic diversity and public space. The journals, however, represent branches and sub-branches in the social sciences, including sociology, psychology, human geography, anthropology, urban studies, architecture and planning, political science, linguistics, economics, and history. Only major journals in archaeology are missing.

A large share of studies were conducted in the Americas (49.1\%). The case studies in the corresponding publications mainly examine (sub)urban settlements and multi-ethnic neighbourhoods in the US (40.2\%). The main focus of these studies is mixed black and white neighbourhoods (Caliendo, 2011; Rollock et al., 2011; Gibson, 2018; Harwood et al., 2018), particularly in New York and Los Angeles. These studies are strongly affiliated with cultural differentiation in the uses of various (semi-)public areas such as schools and parks (Loukaitousideris-Sideris, 1995; Ho et al., 2005; Wolch et al., 2005; Chuang et al., 2013; Kaczynski et al., 2013; Vaughan et al., 2013; Trouille, 2014; Wilson, 2016; Rigolon \& Németh, 2018). These studies mainly focus on children and youth.

"Notable terrorist attacks in the last 15 years, both in the UK and in other countries, have shaped everyday understandings of the public realm as a place that has the potential to be dangerous, and this danger is frequently conflated with racial visibility" (Rishbeth et al., 2017: 42). Accordingly, one breaking point in this review may be related to the global approach to terrorism after the September 11th attacks. The share of case studies in European countries concerning this topic is relatively high (20.1\%). Notably, $14.4 \%$ of the case studies examine the United Kingdom, focusing on British cross-cultural discourse and the ethnographic understandings of ethnically diverse neighbourhoods. Multicultural phenomena and questions about the integration of Muslim minorities and their everyday activities in public spaces are explicit (Schmidt, 2012; Kloek et al., 2013; Mohammad, 2013; Johnson \& Miles, 2014; Hopkins et al., 2017; Joly, 2017). There are also examples of case studies of places where multiculturalism has been present for centuries. A set of studies examines settlements in Palestine and Israel, considers conflict areas between Jews and Arabs, analyses non-recognized autonomous areas, evaluates the status of oppressed communities, and explores the concept of "place" within a multicultural context (Yiftachel \& Yacobi, 2003; Shuval et al., 2009; Monterescu, 2011; Aharon-Gutmann, 2014; Jadallah, 2014; Badarin, 2015; Shtern, 2016; Omer et al., 2018; Rokem \& Vaughan, 2018).

The dataset indicates that current migration trends have also been a subject of investigation. The studies mainly cover research on migrant belonging in cities and contestation and resistance of opposite groups: homeowners and newcomers 


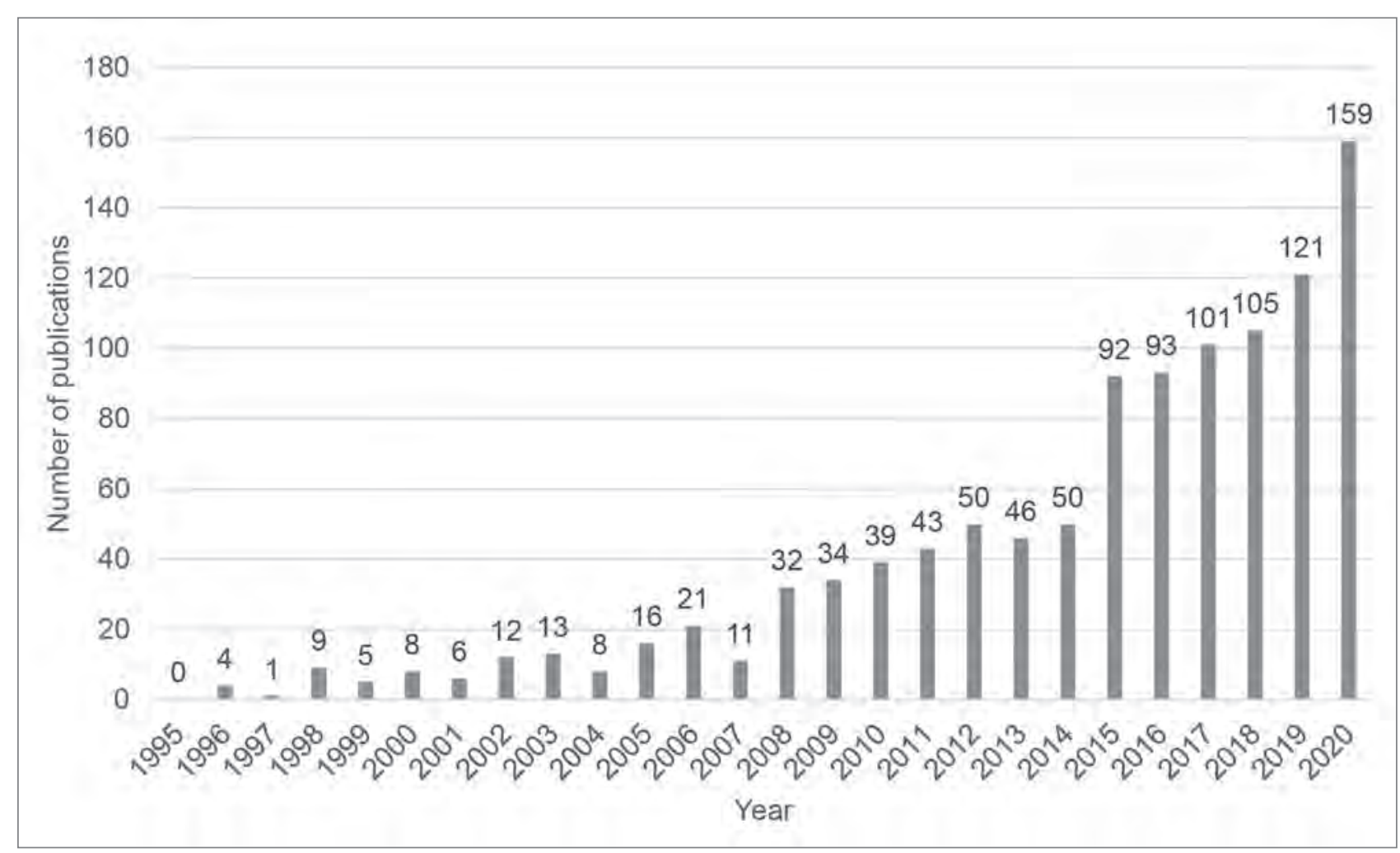

Figure 2: Distribution of the dataset through years (illustration: authors).

Table 2: Research areas included in the dataset.

\begin{tabular}{ll}
\hline Research Area & Frequency \\
\hline Geography & 194 \\
\hline Urban studies & 169 \\
\hline Sociology & 134 \\
\hline Environmental sciences, ecology & 120 \\
\hline Social sciences other topics & 112 \\
\hline Ethnic studies & 102 \\
\hline
\end{tabular}

(Ryan, 2003; Ayata, 2008; Müller, 2011; Ehrkamp, 2013; Triandafyllidou \& Kouki, 2013; Hall, 2015; Lobo, 2015; Demintseva, 2017). The dataset implies that this topic is a central debate subject in everyday politics. Case studies in Asia and Australia mainly focus on ethnically mixed areas caused by migration flows in the distant or recent past. Williamson (2016: 2328) examines whether "forms of belonging are becoming increasingly flexible and are characterized by multiple place attachments by exploring how different scales of belonging and mobility come together in migrant incorporation processes in a hyper-diverse, transitional suburban locality in Sydney, Australia."

\subsection{Thematic areas}

To understand the structure and dynamics of a domain, it is necessary to examine what specific research has been carried out for each major area and how different research areas are connected through specific articles (Chen, 2020: 17). This search process can be divided into two parts. The first part consists of word frequency analysis to examining the dataset based on keywords. By extracting the keywords, main themes are formed, which describe the core content of the dataset. The second part is co-citation analysis. Co-citation of a study shows the occurrence of two or more articles in a third reference list. In such a case, these articles form a co-citation relation, which can be useful for indicating the trends in a research domain.

The keywords public and space evolve parallel to each other and seem to be correlated with consistent appearance over time (Figure 3a). This indicates that research dedicated to urban areas is related to public open spaces. However, these spaces are not only on a city scale but also on a neighbourhood scale because there are a significant number of studies investigating 


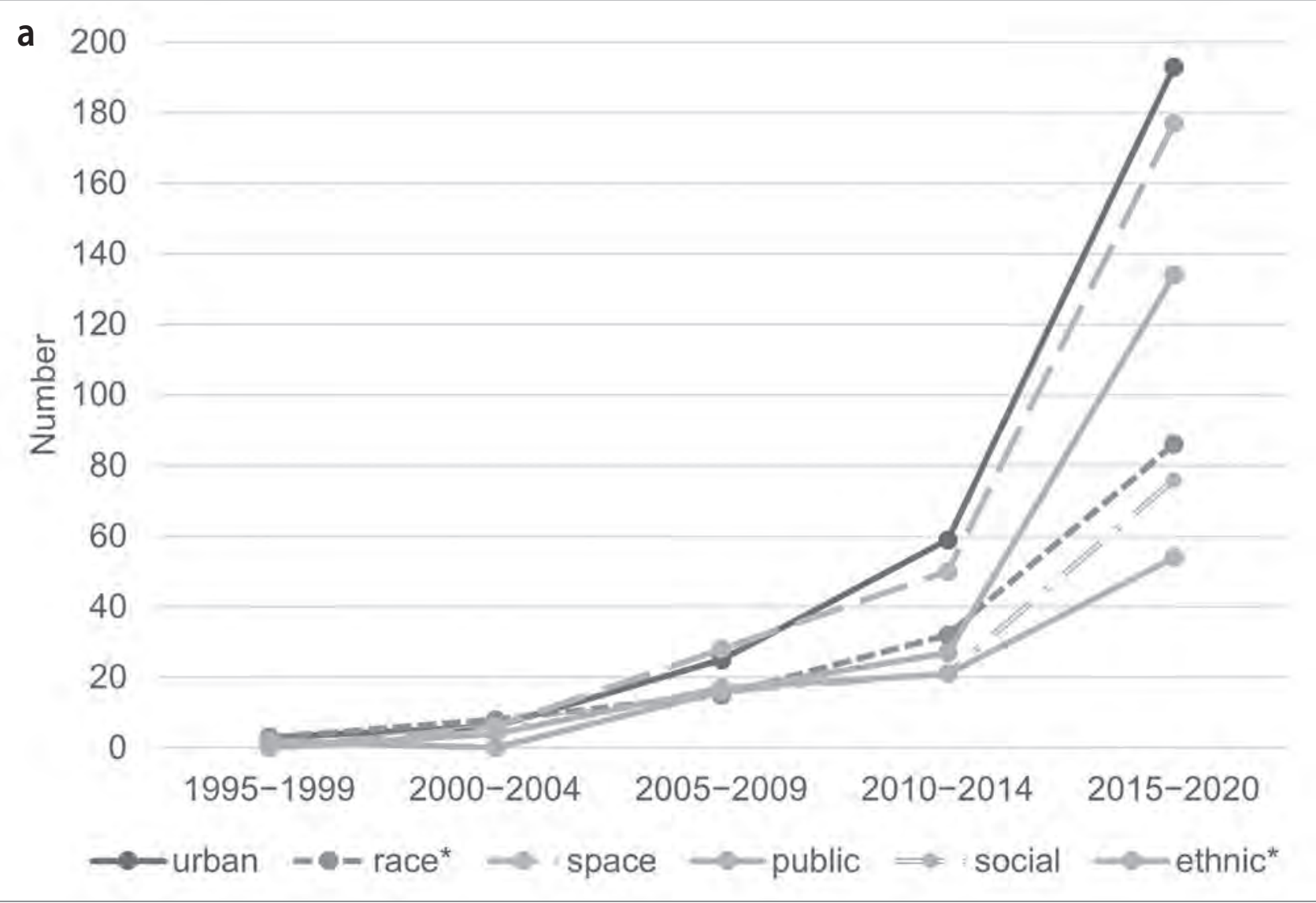

b 100

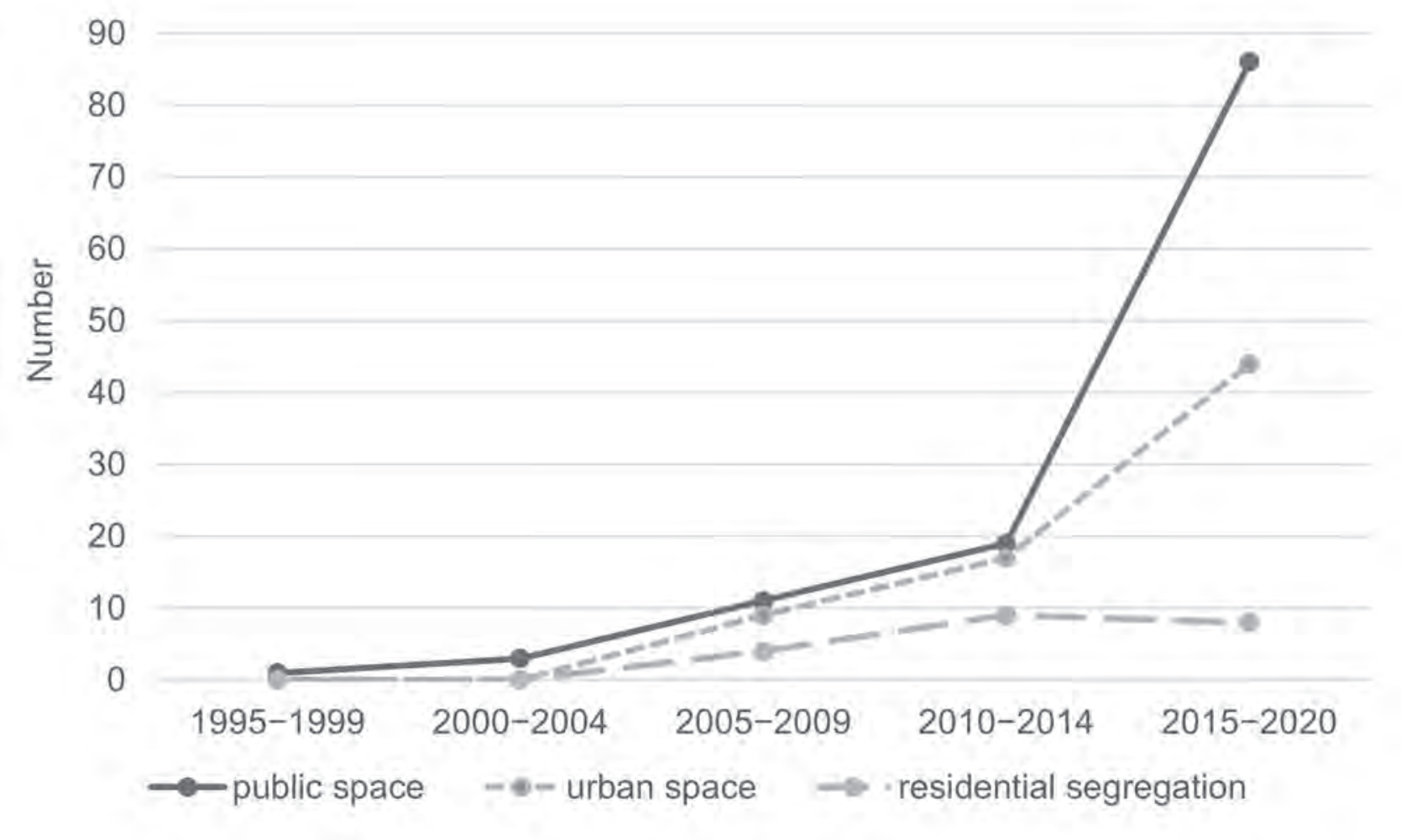

Figure 3: a) most frequent keywords within the time interval; b) most frequent phrases within the time interval (illustration: authors). 


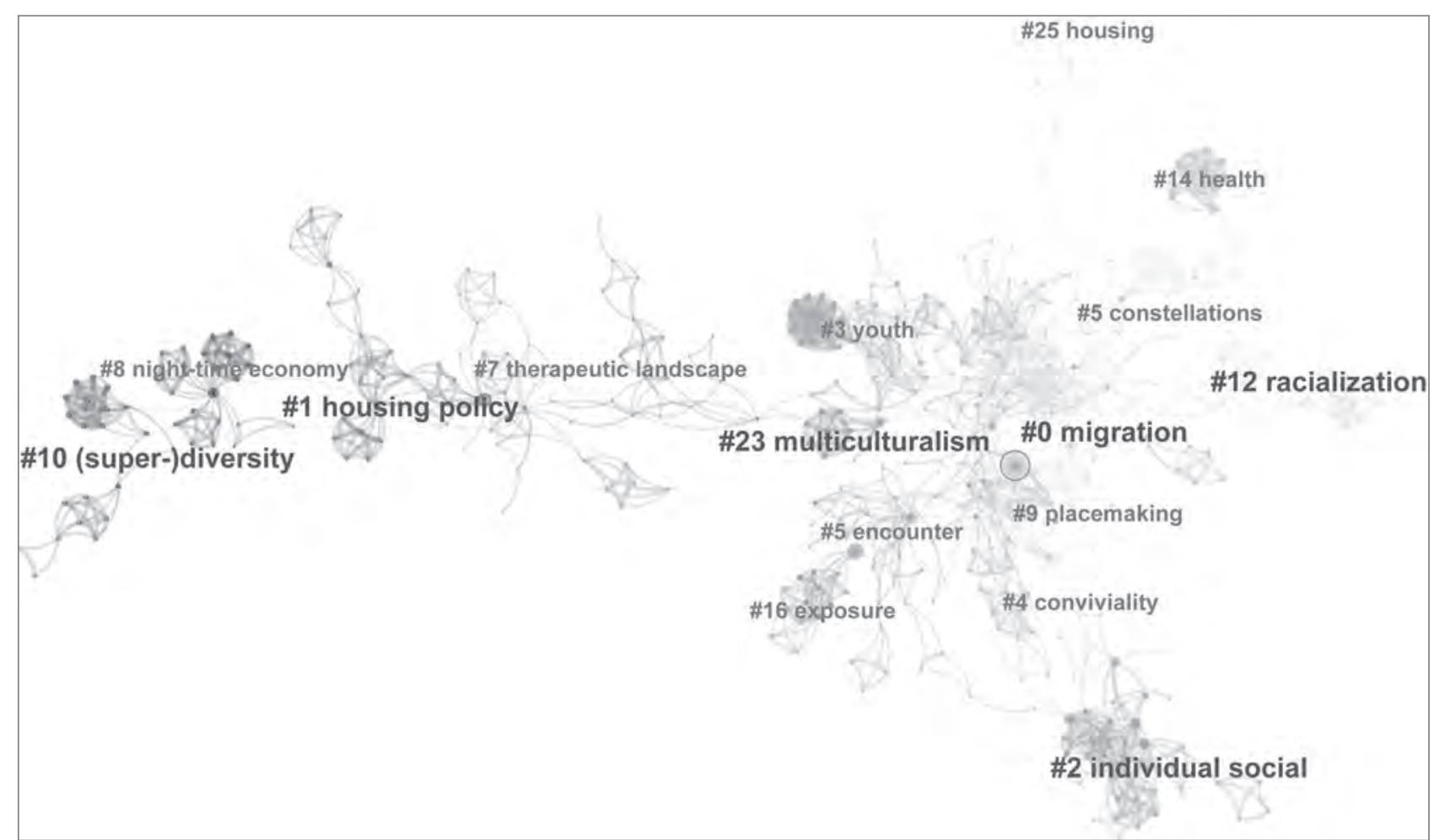

Figure 4: Labelled cluster view of the review dataset (derived from CiteSpace: authors).

residential segregation in diverse neighbourhoods within the urban landscape (Figure 3b). Zsolt Farkas et al. (2017) examine the impacts and consequences of residential segregation in urban spaces in Hungary with a focus on Romani people. Burgers and Zuiderwijk (2016) investigate ethnic segregation in England and Wales. In addition to open urban public spaces, other places as the "common good", such as places for work, education, or leisure, have also been examined. Swyngedouw (2013: 293) explains that "[p]eople of different race and class, represented by the station where they board the train, do not encounter each other much in the L-train because of the existing residential segregation in the city of Chicago." Lobo (2014) explores the lived experience of multiculturalism through the eyes of three people (an Aboriginal, a migrant woman, and herself) by catching the same bus in Darwin, Australia. Jackson (2019) explores contested opinions about a bowling alley in London that is used by diverse ethnic groups and has been threatened with demolition. Schmidt (2015) examines inequity and the variety in access to the school environment using spatiality. Here, the emphasis is on the relation between the social organization and spatial fabric. On the other hand, $\mathrm{Yu}$ et al. (2018) explore college students' spatial perception of a college campus in Memphis. The interpretation of the degree of spatiality and publicness in public space vary in the studies.

A significant amount of the dataset (44.6\%) emphasizes how various parameters are related to ethnicity, fostering diversity, and how this affects the living environment and vice versa.
Disparities are the main concern. The most frequent variables examining the relation between ethnic diversity and public space are segregation, integration, inclusion, exclusion, contact, social interaction, and social cohesion. These parameters encompass multidimensional meanings because they are related to the city as a physical entity, including all its dynamics. For instance, segregation, the most significant variable, has been defined in a broader context (educational segregation, residential segregation, social segregation, or economic segregation) in many studies and is frequently related to urban violence, raising the questions of when and how segregation shapes violence either in the sense of tensions or active conflict (Bhavnani et al., 2013; Trouille, 2014; Kutmanaliev, 2015; Ha, 2017; Zahnow, 2018). To this extent, the keywords indicate that the studies can be categorized into four main themes: 1) multiculturalism (the social phenomena related to the creation of ethnic diversity); 2) relation (containing the indices/parameters measuring the interrelation between ethnic identities or the relation between place and identity);3) space (understood as the public space, the common good as spatial appearance); and 4) city (the constitutional system of networks that reveals socio-spatial relations).

The interrelations of the articles form a co-citation network, which indicates how the publications differ in terms of co-cited references. It simply shows how frequently two articles are cited together by other articles in a dataset (Chen \& Song, 2019). These clusters are themed by index terms from their 


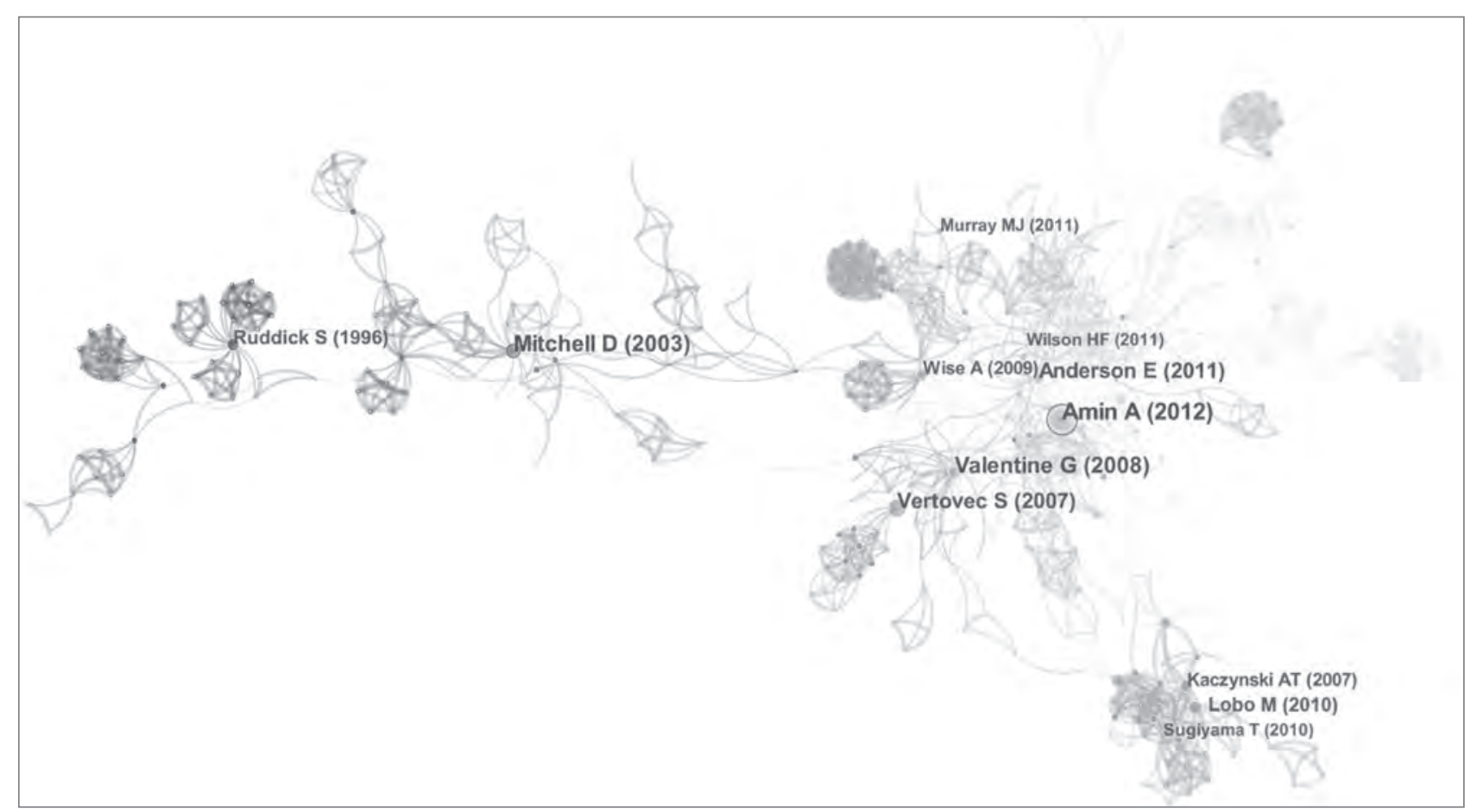

Figure 5: Reference network of the major clusters (derived from CiteSpace: authors).

own citers. A cited author or study may be included in multiple clusters. In correspondence with the dataset, the network is composed of sixteen co-citation clusters, of which six are major clusters (Figure 4). These clusters include interrelated studies and/or authors, which reveal representative approaches to the subject (Figure 5). Furthermore, citation bursts indicate hotspots, attracting a substantial amount of attention within a brief amount of time (Chen, 2016). This signifies certain articles that are frequently cited in a certain time period, which reveals the milestone studies regarding the subject.

\subsubsection{Conceptual cluster 1: human-place relations: a concern for urban and social policy}

The largest cluster $(\# 0)$ is labelled "migration". The most frequently cited author in this cluster is Amin (2012), who considers living with diversity and the role of public space in the city of strangers against contemporary urban policies with regard to the disposal of cohabitation of unwanted groups. Urban policies to manage and foster social cohesion within a society can be created through the study of daily negotiation of ethnic differences in multicultural cities. However, these analyses are limited (Amin, 2002; Fincher \& Iveson, 2008; Valentine, 2008). Understanding the social and spatial processes of diverse user patterns in public space is quite complex and challenging. As Massey (1994: 168) explains, this may be because the notion of place is "formed out of the particular set of social relations which interact at a particular location". He argues that "places do not have to have boundaries in the sense of divisions which frame simple enclosures" (Massey, 1994:
155-156). Instead, "they do not have unique 'identities'; they are full of internal conflicts", and this specificity "derives from the fact that each place is the focus of a distinct mixture of wider and local social relations", with a result that is "progressive; not self-enclosing and defensive and outward-looking" (Massey 1994: 147).

A minor cluster named "placemaking" basically refers to the work of Mitchell (2003), which confronts the reader with a critical statement that the right to the city must be defended through all kinds of diversity to attain social justice. As a matter of fact, this publication has the strongest citation burst (Figure 6). The author defends "the importance of the city as a locus for diversity and the struggle to create a public sphere" (Mitchell, 2003: 18). Hence, the notion of public space is described as the physical environment that allows the representation of an individual's or group's behaviour and thus takes an important step toward creating justice at the management level. When this justice has not been served, less-empowered groups often have difficulty accessing and using everyday public spaces (Mitchell, 1995). Emerging research on migration, asylum policies, refugee agendas, and so on has been reflected in various case studies across the world to examine the political framework and assess the socio-political effects and struggles of ethnic diversity in urban settlements (Lees, 2003; Bryne, 2012; Bhavnani et al., 2013; Festić, 2015; Fredman, 2018). The overall dataset represents a bundle of work that explores "how cultural diversity is experienced and negotiated on the ground in everyday situations" (Wise \& Velayutham, 2009: 2 ) and proposes new politics of diversity appropriate for the 


\begin{tabular}{|c|c|c|c|c|c|}
\hline References & Year & Strength & Begin & End & $1995-2020$ \\
\hline Ruddick S, 1996, URBAN GEOGR, V17, P132, DOI 10.2747/0272-3638.17.2.132, DOI & 1996 & 5.36 & 1999 & 2003 & \\
\hline Day K, 1999, ENVIRON PLANN D, V17, P307, DOI 10.1068/4170307, DOI & 1999 & 3.55 & 2003 & 2006 & \\
\hline Caldeira Teresa, 2000, CITY WALLLS CRIME SEG, VO, P0 & 2000 & 3.48 & 2005 & 2008 & \\
\hline Mitchell D, 2003, RIGHT CITY SOCIAL, JU, VO, PO & 2003 & 7.79 & 2006 & 2011 & \\
\hline Valentine G, 2008, PROG HUM GEOG, V32, P323, DOI 10.117710309133308089372, DOI & 2008 & 5.16 & 2011 & 2016 & \\
\hline Kaczynski AT, 2007, LEISURE SCI, V29, P315, DOI 10.1080/01490400701394865, DOI & 2007 & 383 & 2011 & 2014 & \\
\hline Vertovec S, 2007, ETHNIC RACIALSSTUD, V30, P1024, DOI 10.1080/01419870701599465, DOI & 2007 & 5.66 & 2012 & 2015 & \\
\hline Coben DA, 2007, AM J PUBLIC HEALTH, V97, P509, DOI 10.2105/A.JPH.2005.072447, DOI & 2007 & 3.36 & 2013 & 2014 & \\
\hline AminA, 2012, LAND STRANGERS, Vo, PO & 2012 & 3.85 & 2014 & 2018 & \\
\hline Anderson E, 2011, COSMOPOLITAN CANOPY, VO, PO & 2011 & 478 & 2015 & 2020 & \\
\hline
\end{tabular}

Figure 6: Top references with the strongest citation bursts (illustration: derived from CiteSpace by authors).

present time (Brown, 2006; Amin, 2012). The second-strongest citation burst is related to Vertovec's (2007) work. Due to the strong postcolonial immigration trends in the United Kingdom, the author considers East London and Birmingham as heterogeneous and focuses on migrants' experiences. Herewith, Vertovec introduces the term super-diversity, which recognizes "multiple identifications and axes of differentiation, only some of which concern ethnicity" (2007: 1048). Many other parameters generate inequality between inter- and intra-ethnic groups. These variables include dimensions of religion and class, as well as age, sex, and legal status.

\subsubsection{Conceptual cluster 2: human-human relations: interpersonal interaction and public space as a facilitator}

The second cluster (\#2) is labelled "individual social". By definition, public spaces are "universally accessible, they offer one of the few opportunities for people to directly encounter other people with different behaviours and cultures" (Shaftoe, 2008: 13). Lobo (2010) is the most cited author in the cluster, and his ethnographic study reveals the importance of place attachment as a socio-political concern that forms through everyday intercultural encounters in public spaces. This "provides the potential to blur fixed ethnic boundaries and contribute to interethnic understanding and a sense of belonging" (Lobo, 2010: 85). Several studies discuss similar challenges questioning the importance of urban encounters in public space. Wessel (2009: 7) argues that in everyday interaction "mere exposure to diversity reduces prejudice." However, "proximity does not necessarily bring 'meaningful contact', instead, people who exchange civilities in public might still hold prejudicial views towards minority ethnic groups" (Piekut \& Valentine, 2017: 177). The study with the third-strongest citation burst (Valentine, 2008) establishes that "positive encounters with individuals from minority groups do not necessarily change people's opinions about groups (as a whole) for the better" (Valentine, 2008: 332). "Similarly, quantitative studies have demonstrated that an increase in ethnic diversity in urban space does not directly lead to improved social relations and

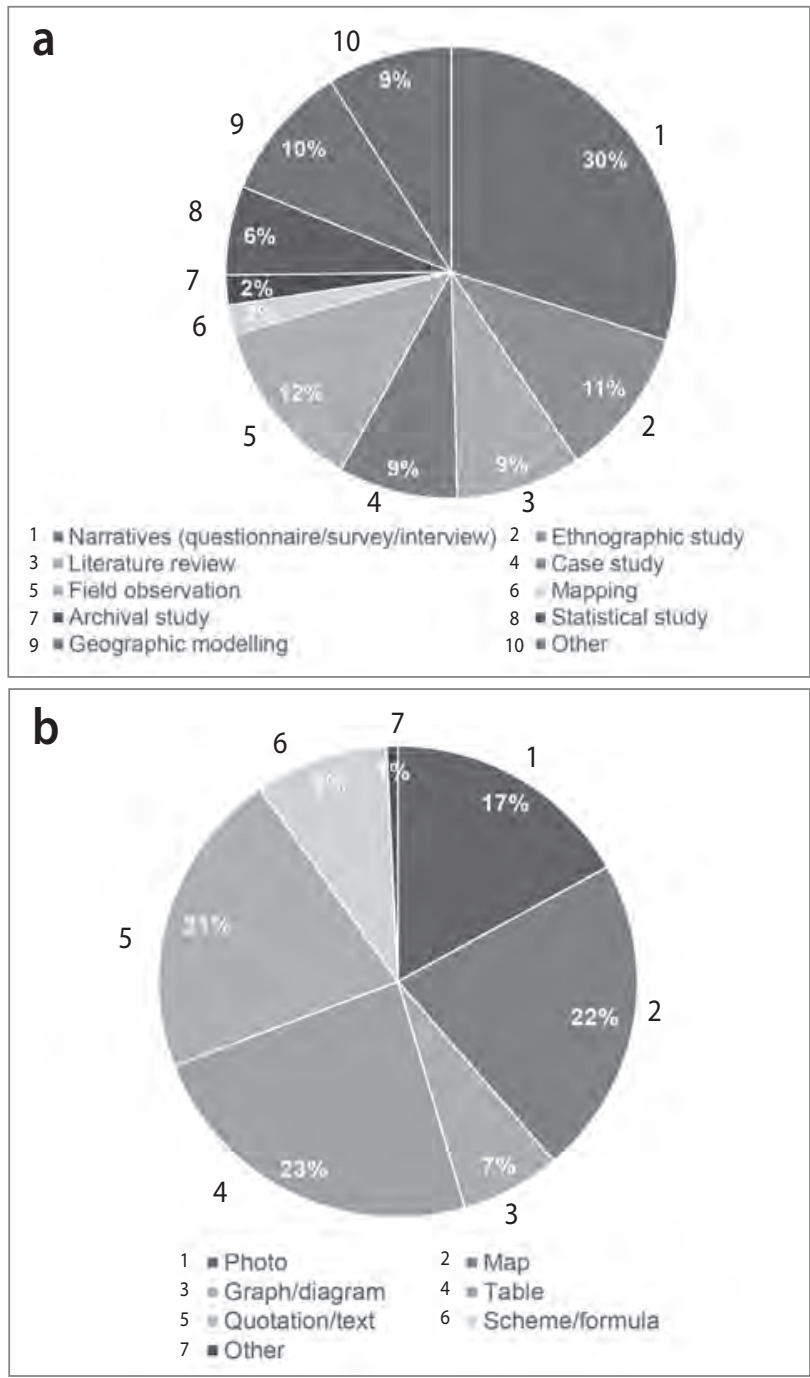

Figure 7: a) distribution of applied methodologies; b) visual representations of the methods used (illustration: authors).

attitudes" (Piekut \& Valentine, 2017: 177). Instead, the studies seek an understanding of the circumstances under which ethnic heterogeneity may lead to tensions (Schlueter \& Scheepers, 2010; Stolle et al., 2013; Laurence, 2014). There are specific studies investigating people's everyday relationships within public space. Cattell et al. (2008: 556) argue that "[a] wide 


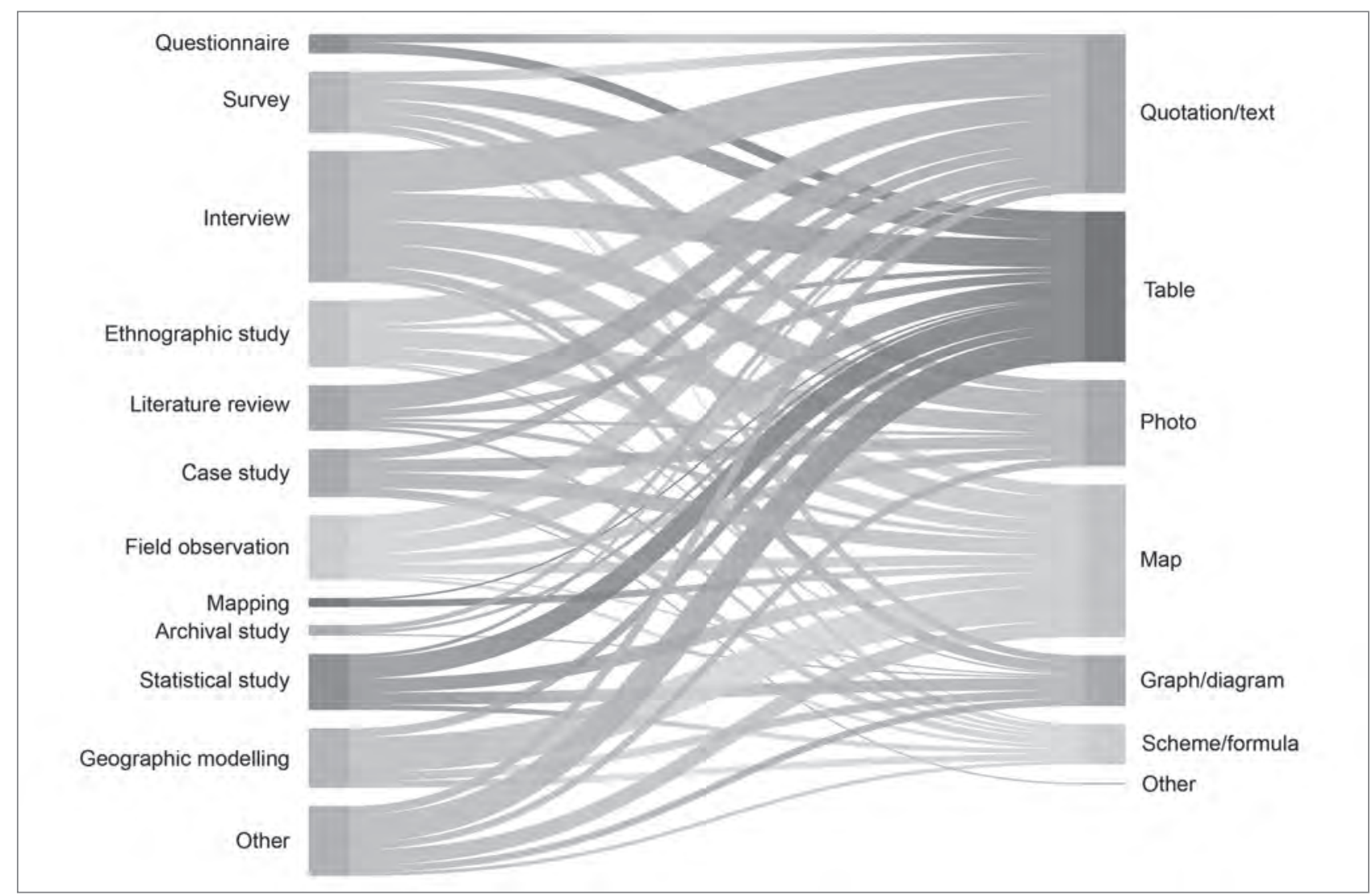

Figure 8: Interrelation of the methodologies applied and their visual representations (illustration: authors).

range of everyday public open spaces were perceived as having a positive influence on both individual well-being and community life." The study emphasizes especially the shared value and collective use of the spaces and how this could contribute to maintaining health and wellbeing. Kazmierczak (2013:31) investigated "the contribution of local parks to the development of social ties" in "three inner-city neighbourhoods in Greater Manchester, UK, characterised by different levels of material deprivation and ethnic diversity." The author claims that, alongside the existing social composition, new or shortterm diffusions are also relevant to focus on.

In summary, this cluster shows that social relations in (socially) isolated territories may have an impact on overcoming or at least reducing differences (Amin, 2002). The discourse focuses either on the majority-minority relation or on the absence on a particular dominant ethnic group. As Gehl (2011) emphasizes regarding varying degrees of contact, the intensities are not directly correlated with their importance. "Compared with the other contact forms, these (low-intensity) contacts appear insignificant, yet they are valuable both as independent contact forms and as prerequisites for other, more complex interactions" (Gehl, 2011: 15). Considering these different approaches, studies have increasingly concentrated on theorizing and examining ethnic encounters in public spaces.

\subsection{Methodological approaches}

We observed that qualitative articles reveal positive or negative effects on public space and test hypotheses, whereas quantitative articles present numerical values for the relation between phenomena by assessing indices and parameters. The studies utilize a mixed-methods approach that includes both qualitative and quantitative data. Qualitative data have been collected using interviews, questionnaires, and observations in narrative forms. In addition, previous literature and archival material were reviewed to support the studies conducted. The results show that 138 articles specifically mentioned using an ethnographic study method, and actually about half of the studies did use it (Figure 7). Ethnographic research aims to understand cultures and norms focusing on human behaviour and collecting observational data (Creswell, 1998, 2003). Given that almost one-fourth of the studies used narratives obtained from interviews, the significance of participatory research must be emphasized. Quantitative data, on the other hand, were collected by using statistical data and mapping and were also obtained through field observations. These observations focus on patterns in everyday activities of public space users. The units of analysis were marginal and minor communities within the case-specific urban settlement. Some other specific case areas were residential neighbourhoods, suburban areas, and 
educational environments such as high schools and university campuses. Focus groups related to these case studies included schoolchildren and college students.

Additional investigation offers an understanding of the relation between the method used and the representation or visualization of the data obtained. Almost every type of methodological approach has been extracted as text, but significant data have also been expressed as visual representation, such as photographs or mappings (Figure 8).

\section{Conclusion}

To prevent deterioration of the social climate, it is crucial to understand interethnic attitudes in public space from different perspectives. The study reveals that relevant literature is generally associated with geography, urban studies, and sociology. However, the selected database corresponds to a wide range of subdisciplines. The literature indicates that there are four main themes to identify regarding the subject: multiculturalism, relation, space, and city. Using bibliometric data analysis, two major co-citation clusters were detected and evaluated based on these themes. The clusters represent the relation between human and place (socio-spatial), and the relation between human and human (socio-physiological).

The largest cluster explores the human-place relation and focuses on ethnic diversity as a concern for urban and social policy. Case studies regarding the cluster treat socio-political effects and struggles particularly associated with migration, asylum policies, and refugee agendas. Moreover, "place" is an essential common good for developing collective and individual public expression. In the second cluster, public space provides a platform to realize social relations and is thus a mediator for ethnic encounters. Nevertheless, investigations of ethnic group behaviour in public space are mainly exploratory. Various empirical research reveals that the contextual effects of ethnic expression are important for understanding the determinants of social relations in settlements. Most of them simply treat ethnicity as a covariate in the analysis of behaviour in public space, and they focus on group differences instead. Here, the emphasis is on the majority-minority ratio of the community. Related literature refers to the physical setting of public space as a site of competition, protest, or negotiation. The link between the clusters establishes that, if justice cannot be served at the administrative level, ethnically disadvantaged groups will have difficulty accessing and using everyday public spaces. Therefore, applying an interdisciplinary framework to the study of multi-ethnic settlements may open doors to dis- cuss issues for policymaking and building peace at the local and global levels.

Tülay Zıvalı Turhan

Ankara Yıldırım Beyazıt University, Faculty of Architecture and Fine Art, Department of Architecture, Ankara, Turkey

E-mail: tturhan@ybu.edu.tr

Hatice Ayataç

Istanbul Technical University, Faculty of Architecture, Department of Urban and Regional Planning, Istanbul, Turkey

E-mail: ayatac@itu.edu.tr

\section{References}

Aharon-Gutman, M. (2014) The iron cage of ethnicity: Ethnic urban enclaves and the challenge of urban design. Urban Design International, 19(1), pp. 144-158. DOI: 10.1057/udi.2013.20

Amin, A. (2002) Ethnicity and the multicultural city: Living with diversity. Environment and Planning, 34(6), pp. 959-980. DOI: 10.1068/a3537

Amin, A. (2012) Land of strangers. Cambridge, Polity.

Andrade, L. F. S., de Pavia, A. L., de Brito, M. J., Garcia, A. S. \& do Prado, J. W. (2016) The right to shape different cities and public realm? A systematic review on "right to the city" scientific production in public administration (1995-2015). Paper presented at XL Encontro do ANPAD, 25-28 September, Costa do Sauípe, Brazil. Typescript.

Ayata, S. (2008) Migrants and changing urban periphery: Social relations, cultural diversity and the public space in Istanbul's new neighbourhoods. International Migration, 46(3), pp. 27-64. DOI: 10.1111/j.1468-2435.2008.00461.x

Back, L. (2015) Why everyday life matters: Class, community and making life liveable. Sociology, 49(5), pp. 820-836. DOI: $10.1177 / 0038038515589292$

Badarin, E. (2015) Settler-colonialist management of entrances to the native urban space in Palestine. Settler Colonial Studies, 5(3), pp. 226235. DOI: 10.1080/2201473X.2014.955946

Bhavnani, R. Donnay, K., Miodownik, D., Mor, M. \& Helbing, D. (2013) Group segregation and urban violence. American Journal of Political Science, 58(1), pp. 226-245. DOI: 10.1111/ajps.12045

Blumer, M. \& Solomos, J. (2015) Multiculturalism, social cohesion and immigration. London, Routledge.

Brown, J. M. (2006) Global South Asians: Introducing the modern diaspora. Cambridge, Cambridge University Press.

DOI: 10.1017/CBO9780511807657

Bryne, J. (2012) When green is white: The cultural politics of race, nature and social exclusion in a Los Angeles urban national park. Geoforum, 43(3), pp. 595-611. DOl: 10.1016/j.geoforum.2011.10.002

Burgers, J. \& Zuiderwijk, L. (2016) At home at the neighborhood square Home Cultures, 13(2), pp. 101-121.

DOI: 10.1080/17406315.2016.1190582

Caliendo, G. G. (2011) MLK Boulevard: Material forms of memory and the social contestation of racial signification. Journal of Black Studies, 42(7), pp. 1148-1170. DOI: 10.1177/0021934711404415

Carmona, M., Heath, T., Oc, T. \& Tiesdell, S. (2003) Public spaces - urban spaces. Oxford, The Architectural Press. 
Cattell, V., Dines, N., Gesler, W. \& Curtis, S. (2008) Mingling, observing, and lingering: Everyday public spaces and their implications for well-being and social relations. Health \& Place, 14(3), pp. 544-561. DOI: 10.1016/j.healthplace.2007.10.007

Charambous Antoniadou, N. \& Peristianis, N. (2001) Ethnic groups, space, and identity. In: Peponis, J., Wineman, J. \& Bafna, S. (eds.) Space syntax: 3rd international symposium, Georgia Institute of Technology, Atlanta, May 7-11 2001: Proceedings. Ann Arbor, MI, A. Alfred Taubman College of Architecture and Urban Planning.

Chen, C. (2016) CiteSpace: A practical guide for mapping scientific literature. New York, Nova Science Publishers.

Chen, C. (2020) How to use CiteSpace. Victoria, BC, Lean Publishing.

Chen C. \& Song, M. (2019) Visualizing a field of research: A methodology of systematic scientometric reviews. PLoS ONE, 14(10), e0223994. DOI: 10.1371/journal.pone.0223994

Chuang, R.-J., Sharma, S., Skala, K. \& Evans, A. (2013) Ethnic differences in the home environment and physical activity behaviors among low-income, minority preschoolers in Texas. American Journal of Health Promotion, 27(4), pp. 270-278. DOI: 10.4278/ajhp.110427-QUAN-171

Creswell, J. W. (1998) Qualitative inquiry and research design: Choosing among five traditions. Thousand Oaks, CA, Sage.

Creswell, J. W. (2003) Research design: Qualitative, quantitative and mixed methods approaches. Thousand Oaks, CA, Sage.

Demintseva, E. (2017) Labour migrants in post-Soviet Moscow: Patterns of settlement. Journal of Ethnic and Migration Studies, 43(15), pp. 25562572. DOI: 10.1080/1369183X.2017.1294053

Dines, N., Cattell, V., Gesler, W. \& Curtis, S. (2006) Public spaces, social relations and well-being in East London. Bristol, Policy Press.

Ehrkamp, P. (2013) "I've had it with them!" Younger migrant women's spatial practices of conformity and resistance. Gender, Place \& Culture, 20(1), pp. 19-36. DOI: 10.1080/0966369X.2011.649356

Ferati, A. (2009) Spatial and ethnic patterns: The interface between "majority" and "minority" in Macedonia. In: Koch, D., Marcus, L. \& Steen, J. (eds.) Proceedings of the 7th International Space Syntax Symposium. Stockholm, KTH.

Festić, F. (2015) Coming to terms with horror: The "ghosts" of the 'ex-Yugoslav' wars and psycho-politics after communism. Chinese Semiotic Studies, 11(2), pp. 181-203. DOI: 10.1515/css-2015-0010

Fincher, R. \& Iveson, K. (2008) Planning and diversity in the city. London, Palgrave Macmillan. DOI: 10.1007/978-1-137-06960-3

Fredman, A. (2018) Perfectionist public space: A political philosophy approach. Space and Polity, 22(1), pp. 30-49.

DOI: 10.1080/13562576.2018.1485216

Gehl, J. (2011) Life between buildings: Using public space. Washington, DC, Island Press.

Gehl, J. \& Gemzoe, L. (1996) Public spaces - Public life. Copenhagen, Danish Architectural Press.

Gibson, D. (2018) When empathy is not enough: A reflection on the self-experience of black boys in public spaces. Pastoral Psychology, 67(1), pp. 611-626. DOI: 10.1007/s11089-018-0837-x

Hall, S. M. (2015) Super-diverse street: A "trans-ethnography" across migrant localities. Ethnic and Racial Studies, 38(1), pp. 22-37. DOI: 10.1080/01419870.2013.858175
Harwood, S. A., Mendenhall, R., Lee, S. S., Riopelle, C. \& Huntt, M. B. (2018) Everyday racism in integrated spaces: Mapping the experiences of students of color at a diversifying predominantly white institution. Annals of the American Association of Geographers, 108(5), pp. 12451259. DOI: $10.1080 / 24694452.2017 .1419122$

Hillier, B. (1996) Space is the machine: A configurational theory of architecture. Cambridge, Cambridge University Press.

Hillier, B., Penn, A., Hanson, J., Grajevski, T. \& Xu, J. (1993) Natural movement: Or, configuration and attraction in urban pedestrian movement. Environment \& Planning B: Planning \& Design, 20(1), pp. 29-66. DOI: $10.1068 / \mathrm{b} 200029$

Ha, H. J. (2017) Emotions of the weak: Violence and ethnic boundaries among Coptic Christians in Egypt. Ethnic and Racial Studies, 40(1), pp. 133-151. DOI: 10.1080/01419870.2016.1201586

Ho, C.-H., Sasidharan, V., Elmendorf, W., Willits, F. K., Graefe, A. \& Godbey, G. (2005) Gender and ethnic variations in urban park preferences, visitation, and perceived benefits. Journal of Leisure Research, 37(3), pp. 281-306. DOI: 10.1080/00222216.2005.11950054

Hopkins, P., Botterill, K., Sanghera, G. \& Arshad, R. (2017) Encountering misrecognition: Being mistaken for being Muslim. Annals of the American Association of Geographers, 107(4), pp. 934-948.

DOI: 10.1080/24694452.2016.1270192

Hutchinson, J. \& Smith, A. D. (1996) Ethnicity. Oxford, Oxford University Press.

Jacobs, J. (1961) The death and life of great American cities. New York, Random House.

Jackson, E. (2019) Valuing the bowling alley: Contestations over the preservation of spaces of everyday urban multiculture in London. The Sociological Review, 67(1), pp. 79-94. DOI: 10.1177/0038026118772784

Jadallah, D. (2014) Colonialist construction in the urban space of Jerusalem. Middle East Journal, 68(1), pp. 77-98. DOI: 10.3751/68.1.14

Johnson, A. M. \& Miles, R. (2014) Toward more inclusive public spaces: Learning from the everyday experiences of Muslim Arab women in New York City. Environment and Planning A: Economy and Space, 46(8), pp. 1892-1907. DOI: 10.1068/a46292

Joly, D. (2017) Women from Muslim communities: Autonomy and capacity of action. Sociology, 51(4), pp. 816-832. DOI: $10.1177 / 0038038515621677$

Kaczynski, A. T., Stanis, S. A., Besenyi, G. M. \& Child, S. (2013) Differences in youth and adult physical activity in park settings by sex and race/ ethnicity. Preventing Chronic Disease, 10, E42.

DOI: $10.5888 /$ pcd10.120276

Kazmierczak, A. (2013) The contribution of local parks to neighbourhood social ties. Landscape and Urban Planning, 109(1), pp. 31-44. DOI: 10.1016/j.landurbplan.2012.05.007

Khoo, C. S. G., Na, J. \& Jaidka, K. (2010) Analysis of the macro-level discourse structure of literature reviews. Online Information Review, 35(2), pp. 255-271. DOI: 10.1108/14684521111128032

Kloek, M. E., Peters, K. \& Sijtsma, M. (2013) How Muslim women in the Netherlands negotiate discrimination during leisure activities. Leisure Sciences, 35(5), pp. 405-421. DOI: 10.1080/01490400.2013.831285

Kutmanaliev, J. (2015) Public and communal spaces and their relation to the spatial dynamics of ethnic riots: Violence and non-violence in the city of Osh. International Journal of Sociology and Social Policy, 35(7/8), pp. 449-477. DOI: 10.1108/IJSSP-02-2015-0027

Laurence, J. (2014) Reconciling the contact and threat hypotheses: Does ethnic diversity strengthen or weaken community inter-ethnic relations? Ethnic and Racial Studies, 37(8), pp. 1328-1349. DOI: 10.1080/01419870.2013.788727 
Le Gentil, E. \& Mongruel, R. (2014) A systematic review of socio-economic assessments in support of coastal zone management (1992-2011). Journal of Environmental Management, 149(1), pp. 85-96. DOI: 10.1016/j.jenvman.2014.10.018

Lees, L. (2003) The ambivalence of diversity and the politics of urban renaissance: The case of youth in downtown Portland, Maine. International Journal of Urban and Regional Research, 27(3), pp. 613-634. DOI: 10.1111/1468-2427.00469

Lobo, M. (2010) Interethnic understanding and belonging in suburban Melbourne. Urban Policy and Research, 28(1), pp. 85-99. DOI: 10.1080/08111140903325424

Lobo, M. (2014) Everyday multiculturalism: Catching the bus in Darwin, Australia. Social \& Cultural Geography, 15(7), pp. 714-729. DOI: 10.1080/14649365.2014.916743

Lobo, M. (2015) Gestures of judgement and welcome in public spaces: Hypervisible migrant newcomers in Darwin, Australia. Journal of Cultural Geography, 32(1), pp. 54-67. DOI: 10.1080/08873631.2015.1005881

Loukaitou-Sideris, A. (1995) Urban form and social context: cultural differentiation in the uses of urban parks. Journal of Planning Education and Research, 14(2), pp. 89-102. DOI: 10.1177/0739456X9501400202

Massey, D. (1994) Space, place and gender. Cambridge, Polity Press.

Mitchell, D. (1995) The end of public space? People's park, definitions of the public, and democracy. Annals of the Association of American Geographers, 85(1), pp. 108-133.

Mitchell, D. (2003) The right to the city: Social justice and the fight for public space. New York, Guilford Press.

Mohammad, R. (2013) Making gender ma(r)king place: Youthful British Pakistani Muslim women's narratives of urban space. Environment and Planning A: Economy and Space, 45(8), pp. 1802-1822. DOI: 10.1068/a45253

Monterescu, D. (2011) Estranged natives and indigenized immigrants: A relational anthropology of ethnically mixed towns in Israel. World Development, 39(2), pp. 270-281. DOI: 10.1016/j.worlddev.2009.11.027

Müller, T. (2011) Interethnic interactions and perceptions of immigrant men in public space: The experience of community safety by seniors in a multicultural neighbourhood. In: Denzin, N. K. \& Faust, T. (eds.) Studies in Symbolic Interaction, pp. 63-78. Bingley, UK, Emerald Group Publishing. DOI: 10.1108/S0163-2396(2011)0000037005

Omer, l., Goldblatt, R., Romann, M. \& Khamaisi, R. (2018) Tolerance, intergroup contacts and municipal-spatial organisation: The case of Jews and Arab Palestinians in the Tel-Aviv metropolitan area. Tijdschrift voor Economische en Sociale Geografie, 109(1), pp. 57-72. DOI: $10.1111 /$ tesg. 12259

Peoples, J. G. \& Bailey, G. (2011) Humanity: An introduction to cultural anthropology. Boston, Wadsworth Publishing.

Piekut, A. \& Valentine, G. (2017) Spaces of encounter and attitudes towards difference: A comparative study of two European cities. Social Science Research, 62(1), pp. 175-188.

DOI: 10.1016/j.ssresearch.2016.08.005

Rigolon, A. \& Németh, J. (2018) Privately owned parks in New Urbanist communities: A study of environmental privilege, equity, and inclusion. Journal of Urban Affairs, 40(4), pp. 543-559.

DOI: 10.1080/07352166.2017.1360739

Rishbeth, C., Ganji, F. \& Vodicka, G. (2018) Ethnographic understandings of ethnically diverse neighbourhoods to inform urban design practice. Local Environment, 23(1), pp. 36-53.

DOI: $10.1080 / 13549839.2017 .1385000$
Rokem, J. \& Vaughan, L. (2018) Segregation, mobility and encounters in Jerusalem: The role of public transport infrastructure in connecting the "divided city". Urban Studies, 55(15), pp. 3454-3473. DOI: $10.1177 / 0042098017691465$

Rollock, N., Gillborn, D., Vincent, C. \& Ball, S. (2011) The public identities of the black middle classes: Managing race in public spaces. Sociology, 45(6), pp. 1078-1093. DOI: 10.1177/0038038511416167

Ryan, L. (2003) Moving spaces and changing places: Irish women's memories of emigration to Britain in the 1930s. Journal of Ethnic and Migration Studies, 29(1), pp. 67-82. DOI: 10.1080/1369183032000076722

Schlueter, E. \& Scheepers, P. (2010) The relationship between outgroup size and anti-outgroup attitudes: A theoretical synthesis and empirical test of group threat- and intergroup contact theory. Social Science Research, 39(2), pp. 285-295. DOI: 10.1016/j.ssresearch.2009.07.006

Schmidt, G. (2012) "Grounded" politics: Manifesting Muslim identity as a political factor and localized identity in Copenhagen. Ethnicities, 12(5), pp. 603-622. DOI: $10.1177 / 1468796811432839$

Schmidt, S. J. (2015) A queer arrangement of school: Using spatiality to understand inequity. Journal of Curriculum Studies, 47(2), pp. 253-273. DOI: 10.1080/00220272.2014.986764

Sennett, R. (2003) The fall of public man. London, Penguin Books Ltd.

Shaftoe, H. (2008) Convivial urban spaces: Creating effective public spaces. Abingdon, Routledge.

Shtern, M. (2016) Urban neoliberalism vs. ethno-national division: The case of West Jerusalem's shopping malls. Cities, 52(1), pp. 132-139. DOI: 10.1016/j.cities.2015.11.019

Shuangyun, Y. \& Hongxia, L. (2020) Knowledge mapping of ethnic identity and acculturation based on the method of bibliometric. Journal of Ethnic and Cultural Studies, 7(3), pp. 17-33. DOI: 10.29333/ejecs/370

Shuval, K., Weissblueth, E., Brezis, M., Araida, A. \& DiPietro, L. (2009) Individual and socioecological correlates of physical activity among Arab and Jewish college students in Israel. Journal of Physical Activity and Health, 6(3), pp. 306-314. DOI: 10.1123/jpah.6.3.306

Stavrides, S. (2016) Common space: The city as commons. London, Zed Books. DOI: 10.5040/9781350219267

Stolle, D., Petermann, S., Schmid, K., Schönwälder, K. Hewstone, M., Vertovec, S., et al. (2013) Immigration-related diversity and trust in German cities: The role of intergroup contact. Journal of Elections, Public Opinion and Parties, 23(3), pp. 279-298. DOI: 10.1080/17457289.2013.809350

$\mathrm{Su}, \mathrm{X}$. Li, X. \& Yanxin, K. (2019) A bibliometric analysis of research on intangible cultural heritage using CiteSpace. SAGE Open, April 2019, pp. 1-18. DOI: $10.1177 / 2158244019840119$

Swyngedouw, E. (2013) The segregation of social interactions in the Red Line L-Train in Chicago. Symbolic Interaction, 36(1), pp. 293-313. DOI: 10.1002/symb.64

Triandafyllidou, A. \& Kouki, H. (2013) Muslim immigrants and the Greek nation: The emergence of nationalist intolerance. Ethnicities, 13(6), pp. 709-728. DOI: 10.1177/1468796813483287

Trouille, D. (2014) Fencing a field: Imagined others in the unfolding of a neighborhood park conflict. City \& Community, 13(1), pp. 69-87. DOI: $10.1111 /$ cico. 12052

Valentine, G. (2008) Living with difference: Reflections on geographies of encounters. Progress in Human Geography, 32(3), pp. 323-337. DOI: 10.1177/0309133308089372 
Vaughan, K. B., Kaczynski, A. T., Wilhelm Stanis, S. A., Besenyi, G. M., Bergstrom, R. \& Heinrich, K. M. (2013) Exploring the distribution of park availability, features, and quality across Kansas City, Missouri by income and race/ethnicity: An environmental justice investigation. Annals of Behavioral Medicine, 45(1), pp. S28-S38. DOI: 10.1007/s12160-012-9425-y

Vertovec, S. (2007) Super-diversity and its implications. Ethnic and Racial Studies, 30(6), pp. 1024-1054. DOI: 10.1080/01419870701599465

Wessel, T. (2009) Does diversity in urban space enhance intergroup contact and tolerance? Geografiska Annaler: Series B, Human Geography, 91(1), pp. 5-17. DOI: 10.1111/j.1468-0467.2009.00303.x

Whyte, W. H. (1980) The social life of small urban spaces. New York, Project for Public Spaces.

Williamson, R. (2016) Everyday space, mobile subjects and place-based belonging in suburban Sydney. Journal of Ethnic and Migration Studies, 42(14), pp. 2328-2344. DOI: 10.1080/1369183X.2016.1205803

Wilson, T. S. (2016) Contesting the public school: Reconsidering charter schools as counterpublics. American Educational Research Journal, 53(4), pp. 919-952. DOI: 10.3102/0002831216658972

Wise, A. \& Velayutham, S. (eds.) (2009) Everyday multiculturalism. London, Palgrave Macmillan. DOI: 10.1057/9780230244474

Wolch, J., Wilson, J. P. \& Fehrenbach, J. (2005) Parks and park funding in Los Angeles: An equity-mapping analysis. Urban Geography, 26(1), pp. 4-35. DOI: 10.2747/0272-3638.26.1.4

Yiftachel, O. \& Yacobi, H. (2003) Urban ethnocracy: Ethnicization and the production of space in an Israeli "mixed city". Environment and Planning D: Society and Space, 21(6), pp. 673-693. DOI: 10.1068/d47j

Yu, S., Bryant, M., Messmer, E., Tsagronis, S. \& Link, S. (2018) "Is there a bubble to burst?" -College students' spatial perception of campus and the city: A case study of Rhodes College in Memphis, TN. Urban Geography, 39(10), pp. 1555-1575. DOI: 10.1080/02723638.2018.1481602

Zahnow, R. (2018) Mixed land use: Implications for violence and property crime. City \& Community, 17(4), pp. 1119-1142.

DOI: 10.1111/cico.12337

Zsolt Farkas, J., Lennert, J., Donát Kovács, A. \& Kanalas, I. (2017) Impacts and consequences of residential segregation of Roma in urban spaces: Case studies from Hungary. Urbani izziv, 28(2), pp. 136-148. DOI: 10.5379/urbani-izziv-en-2017-28-02-005 